\title{
Cerebral Hemodynamic Effects of Treatment with Modified Natural Surfactant Investigated by Near Infrared Spectroscopy
}

\author{
A. D. EDWARDS, D. C. MCCORMICK, S. C. ROTH, C. E. ELWELL, D. M. PEEBLES, M. COPE, \\ J. S. WYATT, D. T. DELPY, AND E. O. R. REYNOLDS \\ Departments of Paediatrics and Medical Physics and Bioengineering, University College and Middlesex School \\ of Medicine, London, United Kingdom
}

\begin{abstract}
The purpose of this study was to investigate the effects on cerebral hemodynamics of administering modified natural surfactant (Curosurf, $200 \mathrm{mg} \cdot \mathrm{kg}^{-1}$ ) to infants requiring mechanical ventilation for hyaline membrane disease. Observations were made using near infrared spectroscopy on 20 infants for between 26 and 109 (median 57) $\mathrm{min}$ before and 22 to 112 (median 46) min after surfactant instillation. Changes in cerebral oxyhemoglobin concentration and cerebral blood volume (CBV) were monitored continuously; cerebral blood flow, oxygen delivery, and the response of $\mathrm{CBV}$ to changes in arterial carbon dioxide tension were measured while the infants were stable shortly before and after surfactant was given. Cerebral oxyhemoglobin concentration fell transiently in all infants immediately after surfactant by a median of $\mathbf{- 0 . 2 1}$ (range -0.46 to 0.05 ) $\mathrm{mL} \cdot 100 \mathrm{~g}^{-1}$, but quickly recovered so that the median change during the $10 \mathrm{~min}$ after surfactant was $0.01(-0.46$ to 0.46$) \mathrm{mL} \cdot 100 \mathrm{~g}^{-1}$. Alterations in CBV also occurred ranging from $\mathbf{- 0 . 4 4}$ to 0.40 (median 0 ) $\mathrm{mL} \cdot 100 \mathrm{~g}^{-1}$, which represented -12 to $16 \%$ of total CBV; these changes rapidly resolved. When the infants were stable before and after surfactant, the values for mean (SD) cerebral blood flow were 20.5 (7.5) and $23.1(5.2) \mathrm{mL} \cdot 100$ $\mathrm{g}^{-1} \cdot \min ^{-1}$, respectively $(n=9)$; for mean cerebral oxygen delivery, values were $2.71(0.89)$ and $3.15(0.73) \mathrm{mL} \cdot 100$ $\mathrm{g}^{-1} \cdot \min ^{-1}(n=9)$; and for response of $\mathrm{CBV}$ to changes in arterial carbon dioxide tension, they were $0.14(0.09)$ and $0.11(0.11) \mathrm{mL} \cdot 100 \mathrm{~g}^{-1} \cdot \mathrm{kPa}^{-1}(n=16)$; these changes were not statistically significant. We conclude that $(1)$ surfactant administration caused small, transient perturbations in cerebral oxyhemoglobin concentration and CBV , and (2) no important alterations in cerebral blood flow, cerebral oxygen delivery, or response of $\mathrm{CBV}$ to changes in arterial carbon dioxide tension were detected. (Pediatr Res 32: 532-536, 1992)
\end{abstract}

\section{Abbreviations}

NIRS, near infrared spectroscopy

$\left[\mathrm{HbO}_{2}\right]$, cerebral oxyhemoglobin concentration

[Hb], cerebral deoxyhemoglobin concentration

$\mathrm{SaO}_{2}$, arterial oxygen saturation

$\mathrm{CBV}$, cerebral blood volume

CBF, cerebral blood flow

COD, cerebral oxygen delivery

$\mathrm{CBVR}$, response of $\mathrm{CBV}$ to changes in $\mathrm{PaCO}_{2}$

Received December 6, 1991; accepted May 21, 1992.

Correspondence: Dr. A. D. Edwards, Department of Paediatrics, University College and Middlesex School of Medicine, Rayne Institute, 5, University St., London WCIE6JJ, United Kingdom.

Supported by the Medical Research Council, the Wellcome Trust, the Wolfson Foundation, Chiesi Farmaceutici, and Hamamatsu Photonics KK.
PAP, peak airway pressure

EEP, end expiratory pressure

$\mathrm{FiO}_{2}$, inspired oxygen fraction

PVH, periventricular cerebral hemorrhage

$\mathrm{PaO}_{2}$, arterial oxygen tension

$\mathrm{PaCO}_{2}$, arterial carbon dioxide tension

There is abundant evidence that surfactant replacement therapy improves pulmonary gas exchange and reduces mortality in infants with hyaline membrane disease (surfactant-deficient respiratory distress syndrome) (1). The effects of this therapy on intracerebral complications, such as PVH, that lead to later morbidity are less certain. Most randomized trials show no evidence of a change in the incidence of PVH in infants treated with either natural or artificial surfactant (1). However, in one recent multicenter trial in which an enriched extract of bovine lung was used, a substantial increase in the incidence of PVH was found (2). Hemorrhages graded as severe occurred in $39 \%$ of treated infants compared with $15 \%$ of controls. Concern about the high incidence of PVH in the treated infants prompted the U.S. Food and Drug Administration to terminate this trial before planned enrollment was completed.

Little information is available about intracerebral consequences of surfactant administration that might provoke $\mathrm{PVH}$, although abnormalities of EEG recordings (3) and falls in cerebral arterial blood velocity (4) have been demonstrated coincident with administration of a natural surfactant derived from porcine lung (Curosurf, Chiesi Farmaceutici, Parma, Italy). The purpose of this study was to investigate with NIRS the extent of any perturbations in cerebral hemodynamics associated with administration of surfactant.

\section{MATERIALS AND METHODS}

Subjects. Twenty newborn infants who had been admitted to the Neonatal Unit of University College Hospital were studied; 10 were male and 10 female. Their gestational ages ranged from 24 to 34 (median 27) wk and their birth weights ranged from 0.71 to 2.10 (median 1.00 ) $\mathrm{kg}$. The infants met the criteria for entry into the Curosurf 4 multicenter trial: they had the typical clinical and radiologic features of hyaline membrane disease with an arterial to alveolar oxygen ratio less than 0.22 , and they were intubated and receiving mechanical ventilation with Bourns BP200 (Specialised Laboratory Equipment, Croydon, UK) or SLE 150 (Specialised Laboratory Equipment) ventilators. No infant had a known major congenital abnormality at the time of study, although one infant was subsequently found to have coarctation of the aorta. All infants were being treated with gentamicin and 
benzylpenicillin $(n=19)$ or ceftazidime $(n=1)$; two were musclerelaxed with pancuronium, one was receiving infusions of dobutamine and prostacyclin, and another was receiving tolazoline. Continuous estimations of $\mathrm{PaO}_{2}$ and $\mathrm{PaCO}_{2}$ were made with skin electrodes (HP 78834A, Hewlett-Packard Co., Palo Alto, CA) calibrated using samples of arterial blood. $\mathrm{SaO}_{2}$ was measured continuously on every heartbeat using a modified pulse oximeter (Type BF, Nellcor, Haywood, CA) and arterial blood pressure was measured by a transducer (HP 78834A, Hewlett-Packard) connected to an umbilical artery catheter. Cerebral ultrasound scans (Ultramark 4, Advanced Technical Laboratories, Letchworth, UK) were performed in all infants at least once before surfactant and repeatedly afterwards until the time of death or discharge.

Consent for the investigation was obtained from the infant's parents before each study, and the project was approved by the University College London Faculty of Clinical Sciences Committee on the Ethics of Clinical Investigation.

Surfactant administration. Studies were begun when the infants were between 2 and 15 (median 8) h old. Curosurf was administered in a dose of $200 \mathrm{mg} \cdot \mathrm{kg}^{-1}\left(2.5 \mathrm{~mL} \cdot \mathrm{kg}^{-1}\right)$ of body weight. When infants received multiple doses, only the effects of the first dose were studied. The infant, nursed supine with the head in the midline, was disconnected from the ventilator circuit and a polythene catheter that passed easily down the endotracheal tube was inserted until the catheter tip rested at the end of the tube. The surfactant was instilled through the catheter as a single bolus over about 2 to $4 \mathrm{~s}$ with the head immobile. Mechanical ventilation was immediately restarted using the previous ventilator settings. The aim was to alter $\mathrm{FiO}_{2}$ so that the $\mathrm{PaO}_{2}$ remained within clinically acceptable limits $(8-12 \mathrm{kPa})$ and to manipulate the peak airway pressure so that the chest movements appeared normal and the $\mathrm{PaCO}_{2}$ remained at a satisfactory level.

Near infrared spectroscopy. Studies by NIRS were carried out for between 26 and 109 (median 57) min before and 22 to 112 (median 46) min after administration of surfactant. The technique depends on measuring the characteristic absorption, within cerebral tissue, of near infrared light by the chromophores oxyhemoglobin and deoxyhemoglobin (5). The apparatus used were the NIR 1000 or the NIR 500 (Hamamatsu Photonics KK, Hamamatsu City, Japan), which were commercial prototypes of the machine designed and built at this institution (6).

We have previously described the methods used to measure changes in intracerebral $\left[\mathrm{HbO}_{2}\right]$ and $[\mathrm{Hb}](7), \mathrm{CBV}(8)$, and its reactivity to alterations in $\mathrm{PaCO}_{2}$ (CBVR) (9), as well as CBF (10) and COD. Briefly, near infrared light at three (NIR 500) or six (NIR 1000) wavelengths between 779.0 and $907.8 \mathrm{~nm}$ was carried to the infant's head through a fiberoptic bundle, the end of which (the optode) was applied to the parietal region. Light emerging from the head was collected from another optode at least $4 \mathrm{~cm}$ distant from the first and transmitted to the photomultiplier tube of the spectrometer. The distance between the optodes was measured with mechanical callipers. To prevent interference from background illumination, the infant's head was wrapped in a light-tight bandage.

Changes in intracerebral $\left[\mathrm{HbO}_{2}\right]$ and $[\mathrm{Hb}]$ were calculated from the modified Lambert-Beer law using previously established extinction coefficients (11) and assuming an optical path length of 4.39 times the distance between the optodes (12). Measurements were made continuously and averaged into variable time bins for display at the cotside, and the data were recorded on computer disc for later analysis.

Changes in total cerebral hemoglobin concentration ([tHb]) were calculated as the sum of the changes in $\left[\mathrm{HbO}_{2}\right]$ and $[\mathrm{Hb}]$, and changes in CBV (mL.100 $\mathrm{g}^{-1}$ ) was calculated from the formula (7):

$$
\Delta \mathrm{CBV}=\mathrm{k}_{1} \cdot(\Delta[\mathrm{tHb}] /[\mathrm{H}])
$$

where $k_{1}$ is a constant $(0.89)$ reflecting the molecular weight of hemoglobin (64500), tissue density (1.05) (13), and cere- bral:arterial hematocrit ratio $(0.69)(14) ;[\mathrm{H}]$ is peripheral arterial $\mathrm{Hb}$ concentration.

Absolute values for total CBV (mL.100 g $\mathrm{g}^{-1}$ ) were obtained after observing the effect of a change of $5-10 \%$ in $\mathrm{SaO}_{2}$ produced over a period of about $5 \mathrm{~min}$ by altering the $\mathrm{FiO}_{2}$. CBV was calculated from the following formula (8):

$$
\mathrm{CBV}=\mathrm{k}_{1} \cdot\left(\Delta\left[\mathrm{HbO}_{2}\right]-\Delta[\mathrm{Hb}]\right) /\left(2 \cdot[\mathrm{H}] \cdot \Delta \mathrm{SaO}_{2}\right)
$$

CBVR ( $\mathrm{mL} \cdot 100 \mathrm{~g}^{-1} \cdot \mathrm{kPa}$ ) was measured after inducing a change in $\mathrm{PaCO}_{2}$ of about $1 \mathrm{kPa}$ within or toward the normal range by altering the ventilator rate and observing the effect on CBV (9).

$\mathrm{CBF}\left(\mathrm{mL} \cdot 100 \mathrm{~g}^{-1} \cdot \mathrm{min}^{-1}\right)$ was estimated using a modification of the Fick principle in which a sudden change in $\mathrm{SaO}_{2}$ over 4-6 $s$ induces a change in oxyhemoglobin, which acts as an intravascular and nondiffusible tracer. $\mathrm{CBF}$ was calculated from the expression (10)

$$
\mathrm{CBF}=\frac{\mathrm{k}_{2} \cdot \Delta\left[\mathrm{HbO}_{2}\right](\mathrm{t})}{[\mathrm{H}] \cdot \int_{0}^{\mathrm{t}}\left(\Delta \mathrm{SaO}_{2}\right) \mathrm{dt}}
$$

where $\mathrm{k}_{2}$ is a constant reflecting the molecular weight of $\mathrm{Hb}$ and tissue density. [Independent studies have shown that this method gave results comparable to those obtained with the i.v. ${ }^{133}$ Xenon clearance technique in preterm infants $(15,16)$.] COD was calculated as the product of arterial oxygen content and CBF.

Statistical analysis. The data were examined to ascertain which samples approximated a normal distribution: if the median and the mean were similar, the SD was calculated; otherwise, the range was determined. Mean $\mathrm{CBF}$, mean $\mathrm{COD}$, and CBVR before and after surfactant were compared using paired $t$ test. The maximum changes in percentage of CBV in infants who subsequently developed PVH were compared with those who did not using the rank sum test, and, using the same test, $\mathrm{FiO}_{2}$ and PAP were compared in infants with and without CBF measurements. Using the SPSS-PC statistical package, changes in $\left[\mathrm{HbO}_{2}\right], \mathrm{CBV}$, and $\mathrm{CBF}$ were analyzed using stepwise multiple linear regression analysis, with the probability of $F$ required for entry into the model set at $0.05 . \mathrm{PaCO}_{2}, \mathrm{PaO}_{2}$, mean arterial blood pressure, and surfactant administration were analyzed as independent variables, together with a factor to account for variability between individuals. The partitioning of variance was analyzed to determine important correlations. Histograms of studentized residuals were examined, significant outliers were investigated, and relations between variables and residuals were sought to check the applicability of the model.

\section{RESULTS}

Ventilator management. Immediately after instillation of surfactant, small increases in both peak airway pressure (PAP) and $\mathrm{FiO}_{2}$ were generally needed to maintain satisfactory chest expansion and $\mathrm{SaO}_{2}$. One-half to $1 \mathrm{~min}$ later, it was usually possible to decrease both. One $h$ before surfactant treatment, the median value for PAP was $25(18-45) \mathrm{cm} \mathrm{H}_{2} \mathrm{O}$, EEP was $3(2-5) \mathrm{cm}$ $\mathrm{H}_{2} \mathrm{O}$, ventilator rate was $30(20-36)$ breaths $\cdot \min ^{-1}$, the inspiration:expiration ratio was $1.0(1.0-2.0)$, and $\mathrm{FiO}_{2}$ was $0.72(0.35-$ 1.00). Individual values for PAP, EEP, and $\mathrm{FiO}_{2}$ before and during the $10 \mathrm{~min}$ after surfactant are shown in Figure 1. One $h$ after treatment, the median value for PAP was $24(18-34) \mathrm{cm}$ $\mathrm{H}_{2} \mathrm{O}$, EEP was $3(2-5) \mathrm{cm} \mathrm{H}_{2} \mathrm{O}$, ventilator rate was $30(20-50)$ breaths $\mathrm{min}^{-1}$, the inspiration:expiration ratio was $1.0(0.6-1.5)$, and $\mathrm{FiO}_{2}$ was $0.35(0.21-1.0)$. Values for $\mathrm{PaO}_{2}, \mathrm{PaCO}_{2}$, and mean arterial blood pressure before and after treatment are given in Table 1.

Changes in $\left[\mathrm{HbO}_{2}\right]$ and $\mathrm{CBV}$ during surfactant administration. Figure 2 illustrates the acute changes in $\left[\mathrm{HbO}_{2}\right]$ and $\mathrm{CBV}$ obtained from continuous measurements averaged over 20 -s pe- 


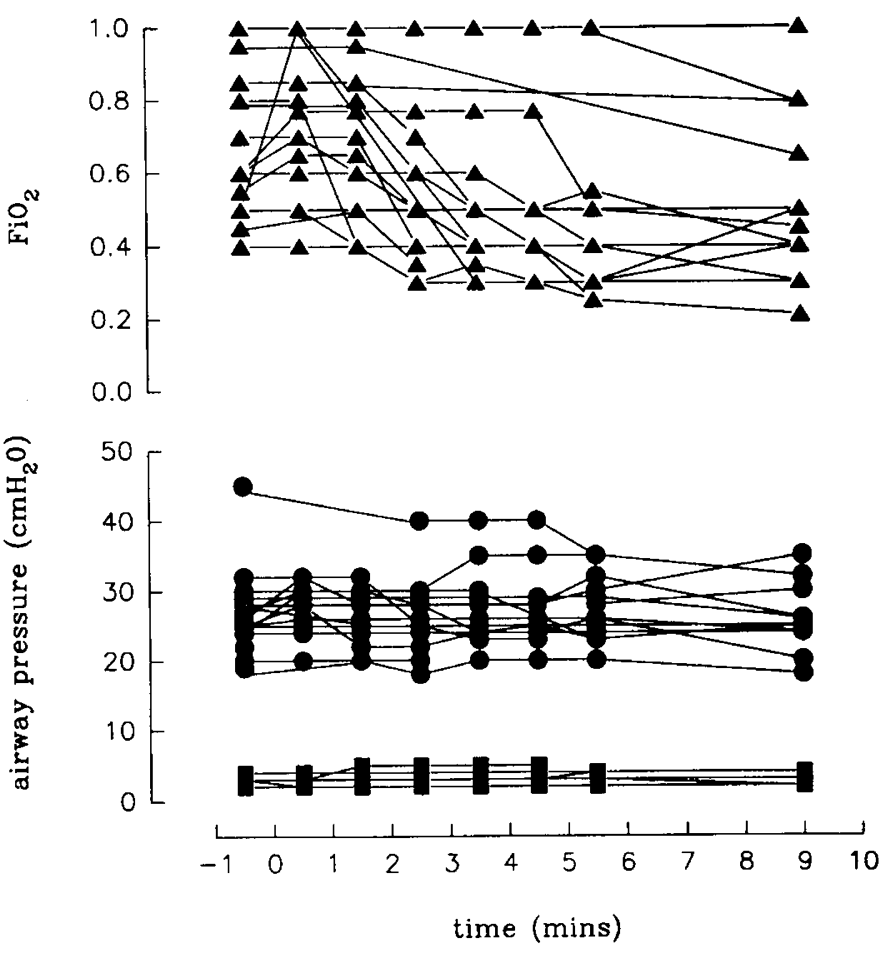

Fig. 1. $\mathrm{FiO}_{2}$, PAP, and EEP before and after surfactant, which was administered at $0 \min (n=16-20)$. PAP; $\mathbf{\square}$, EEP. Some data points are superimposed.

riods, and Table 1 gives median values for the $5 \mathrm{~min}$ before and $10 \mathrm{~min}$ after treatment.

Immediately after disconnection from the ventilator and instillation of surfactant, $\left[\mathrm{HbO}_{2}\right]$ fell transiently from baseline values (Fig. 2). The maximum fall in each infant ranged from -0.46 to 0.05 (median -0.21 ) $\mathrm{mL} \cdot 100 \mathrm{~g}^{-1}$. This rapidly reversed so that no net change was seen in the group as a whole during the 10 min after surfactant (Table 1). Multiple linear regression analysis showed that surfactant administration had a weak independent relation with $\left[\mathrm{HbO}_{2}\right]$ but that the largest part of the variation in $\left[\mathrm{HbO}_{2}\right]$ was explained by a strong positive relation to changes in $\mathrm{PaO}_{2}(p<0.01)$. This was not an independent effect of surfactant, because $\mathrm{FiO}_{2}$ was adjusted as part of the administration protocol.

The alteration in CBV immediately after surfactant was inconsistent, ranging from -0.44 to 0.40 (median 0 ) $\mathrm{mL} \cdot 100 \mathrm{~g}^{-1}$ (Fig. 1). The maximum change observed expressed as a percentage of total CBV ranged from -12 to $16 \%$ (median $0 \%$ ). The changes were transient, and there was no change in the group median (Table 1) although, as with $\left[\mathrm{HbO}_{2}\right]$, increased variation in $\mathrm{CBV}$ after surfactant was observed. Multiple linear regression showed that changes in $\mathrm{CBV}$ were not independently related to surfactant administration. Changes in $\mathrm{CBV}$ had a strong positive correlation with $\mathrm{PaCO}_{2}(p<0.001)$ and a slight negative relation to $\mathrm{PaO}_{2}$ $(p<0.01)$; no relation to mean arterial blood pressure was found. The maximum percentage change in CBV after surfactant was not significantly different in infants who subsequently de- veloped PVH compared to those who did not, or in infants in whom CBF was measured compared to the remainder.

Values for total CBV before surfactant administration were obtained in 19 infants and ranged from 1.2 to 6.0 (median 3.0) $\mathrm{mL} \cdot 100 \mathrm{~g}^{-1}$. The median percentage of change in CBV after surfactant is included in Table 1.

$C B F, C O D$, and $C B V R$ before and after surfactant administration. CBF was measured in nine infants between 6 and 79 (median 23) min before and 11 and 70 (median 26) min after surfactant. Between one and three (median 2) measurements were made in each infant before and between one and four (3) afterwards. $\mathrm{COD}$ was calculated, and individual values for $\mathrm{CBF}$ and COD are shown in Figure 3. Mean values for these variables in each infant are given in Table 2. No significant effect of surfactant administration could be demonstrated by paired $t$ test. Multiple linear regression showed a highly significant relation between CBF and $\mathrm{PaCO}_{2}$ of $3.4 \mathrm{~mL} \cdot 100 \mathrm{~g}^{-1} \cdot \mathrm{min}^{-1} \cdot \mathrm{kPa}^{-1}(p<$ 0.001 ) as illustrated in Figure 4. No relation was found between $\mathrm{CBF}$ and surfactant administration, $\mathrm{PaO}_{2}$, or mean arterial blood pressure. The infants in whom CBF was measured had lower initial median $\mathrm{FiO}_{2}$ and PAP compared to the rest of the group (0.50:0.90 and $24: 28 \mathrm{~cm} \mathrm{H}_{2} \mathrm{O}$, respectively), but this difference was not statistically significant.

CBVR was tested in 16 infants between 10 and 61 (median 29) min before and between 7 and 80 (median 26) min after surfactant. The median imposed alteration in $\mathrm{PaCO}_{2}$ was 0.9 $(0.5-1.7) \mathrm{kPa}$. The individual results are included in Figure 3 and mean values are shown in Table 2; no significant change after surfactant administration was found.

Analysis of the distributions of residuals from the various regression models showed that they approximated a gaussian distribution and were unrelated to any variable.

Other results. Cerebral ultrasound scans were normal in 18 of the 20 infants before surfactant; one infant had a germinal layer hemorrhage and another had moderate ventricular dilatation of unknown etiology. In the $7 \mathrm{~d}$ after surfactant, three infants developed germinal layer hemorrhages, three developed intraventricular hemorrhages, and three developed hemorrhagic parenchymal infarction. One infant with a large intraventricular hemorrhage later developed periventricular leukomalacia. No relation was found between the variables studied and subsequent hemorrhage.

Four infants died, two from the direct effects of their lung disease and two in association with hemorrhagic parenchymal infarction.

\section{DISCUSSION}

Numerous investigators have implicated cerebral hemodynamic perturbations in the pathogenesis of PVH, and some evidence suggests that strategies that diminish these perturbations reduce the risk of bleeding $(17,18)$. It therefore seemed possible that surfactant instillation could under some circumstances induce hemodynamic consequences that might provoke PVH among treated infants, as appears to have been the case in the study of Horbar et al. (2). Evidence consistent with this hypothesis was obtained by Svenningsen et al. (3), who gathered EEG data showing periods of electrical silence lasting up to $20 \mathrm{~min}$ after the administration of surfactant, which they interpreted as

Table 1. Median (range) values for maximum changes in $\left[\mathrm{HbO}_{2}\right], \mathrm{CBV}$, and percentage change of total $\mathrm{CBV}$, with mean (SD) values for $\mathrm{PaCO}_{2}, \mathrm{PaO}_{2}$, and mean arterial blood pressure during $5 \mathrm{~min}$ before and 10 min after surfactant instillation

\begin{tabular}{lcc}
\hline & Before surfactant & After surfactant \\
\hline$\Delta\left[\mathrm{HbO}_{2}\right]\left(\mathrm{mL} \cdot 100 \mathrm{~g}^{-1}\right)$ & $-0.01(-0.22,0.13)$ & $0.01(-0.46,0.46)$ \\
$\Delta \mathrm{CBV}\left(\mathrm{mL} \cdot 100 \mathrm{~g}^{-1}\right)$ & $0(-0.11,0.16)$ & $0(-0.44,0.40)$ \\
$\Delta \mathrm{CBV} \%(n=19)$ & $0(-1,4)$ & $0(-12,16)$ \\
$\mathrm{PaCO}_{2}(\mathrm{kPa})$ & $7.1(2.0)$ & $7.9(2.0)$ \\
$\mathrm{PaO}_{2}(\mathrm{kPa})$ & $9.4(1.5)$ & $10.7(2.3)$ \\
$\mathrm{Mean}$ arterial pressure $(\mathrm{mm} \mathrm{Hg})$ & $29.7(5.7)$ & $28.6(6.4)$ \\
\hline
\end{tabular}



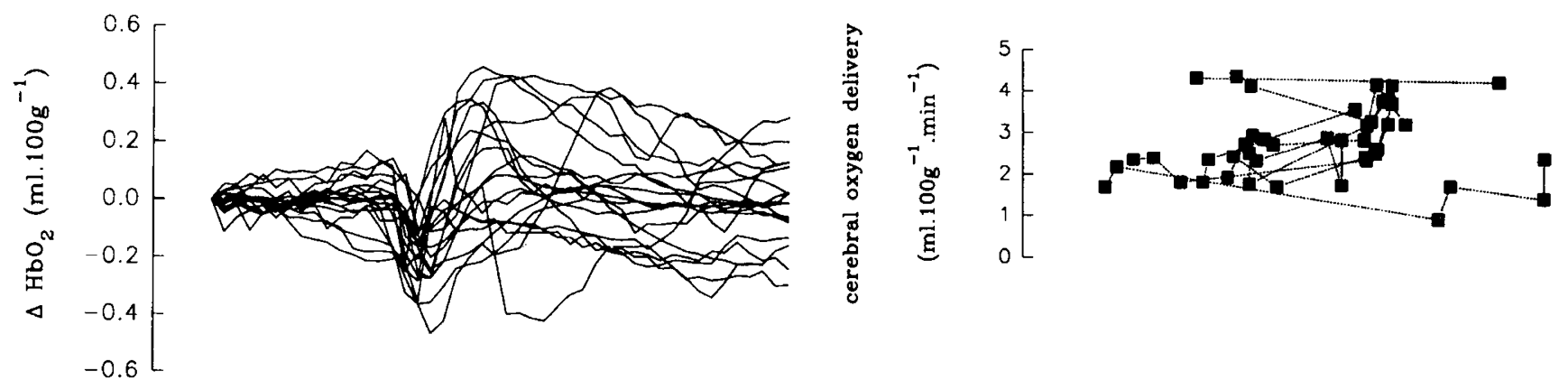
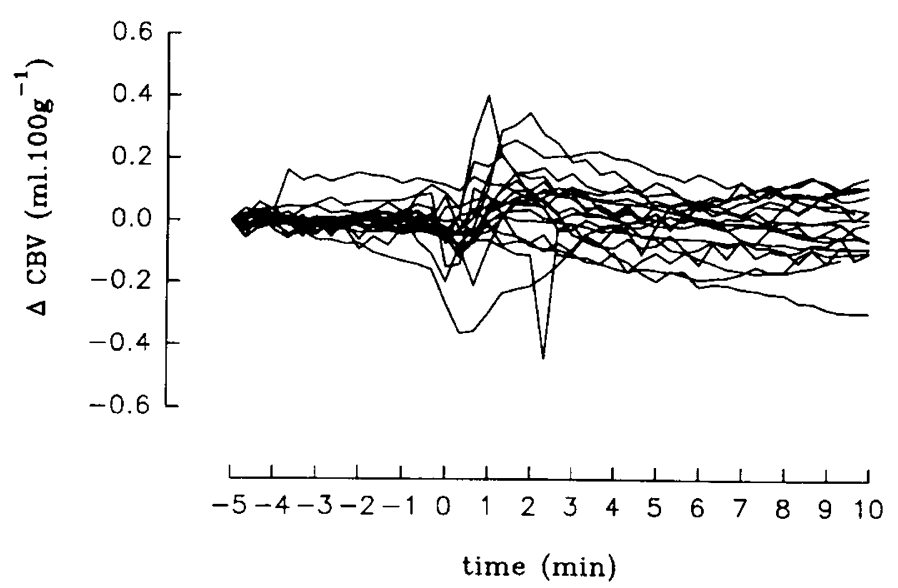

Fig. 2. Changes from an arbitrary zero in $\left[\mathrm{HbO}_{2}\right]$ and $\mathrm{CBV}$ from 5 min before until $10 \mathrm{~min}$ after surfactant administration $(n=20)$. Surfactant was administered at $0 \mathrm{~min}$.

evidence of cerebral ischemia (3). The persistent reduction of $36 \%$ in middle cerebral artery blood velocity after surfactant administration found by Cowan et al. (4) was also interpreted as resulting from a fall in cerebral blood flow (4). We have used NIRS to make quantitative observations of cerebral hemodynamic events associated with surfactant instillation.

The indications for giving surfactant in the present study were identical to the criteria defined in a current multicenter randomized trial of surfactant. The infants were all diagnosed as having hyaline membrane disease due to surfactant deficiency, and administration of surfactant usually allowed the expected reduction in $\mathrm{FiO}_{2}$. The severity of lung disease varied among the infants, but overall they appeared representative of infants who currently receive surfactant therapy. Our aim during and after instillation was to minimize alterations to chest movement and blood gases in the belief that this would probably minimize hemodynamic perturbations. We therefore altered ventilation pressures so that chest wall movements appeared satisfactory at the same time as manipulating $\mathrm{FiO}_{2}$ to maintain normal oxygenation.

Our results showed that when surfactant was administered there were immediate small fluctuations in $\left[\mathrm{HbO}_{2}\right]$ and $\mathrm{CBV}$ (Fig. 3). A rapid but short-lived decline in $\left[\mathrm{HbO}_{2}\right]$ took place, which was related to the fall in $\mathrm{PaO}_{2}$ caused by disconnection from the ventilator. $\left[\mathrm{HbO}_{2}\right]$ recovered on reconnection and there was no persisting decline in cerebral oxygenation. The acute alterations in CBV that were observed in all infants after surfactant were closely related to changes in $\mathrm{PaO}_{2}$ and $\mathrm{PaCO}_{2}$. Transient alterations of -12 to $16 \%$ of $\mathrm{CBV}$ were observed, probably related to changes in venous blood volume. However, changes, of this order have been observed during endotracheal suction (19), and the falls in CBV were considerably smaller than the persistent falls that follow the administration of indomethacin to preterm infants for treatment of patent ductus arteriosus (20). The median of the maximum change in $\mathrm{CBV}$ was $0 \%$.

Comparison of values for $\mathrm{CBF}, \mathrm{COD}$, and CBVR made shortly
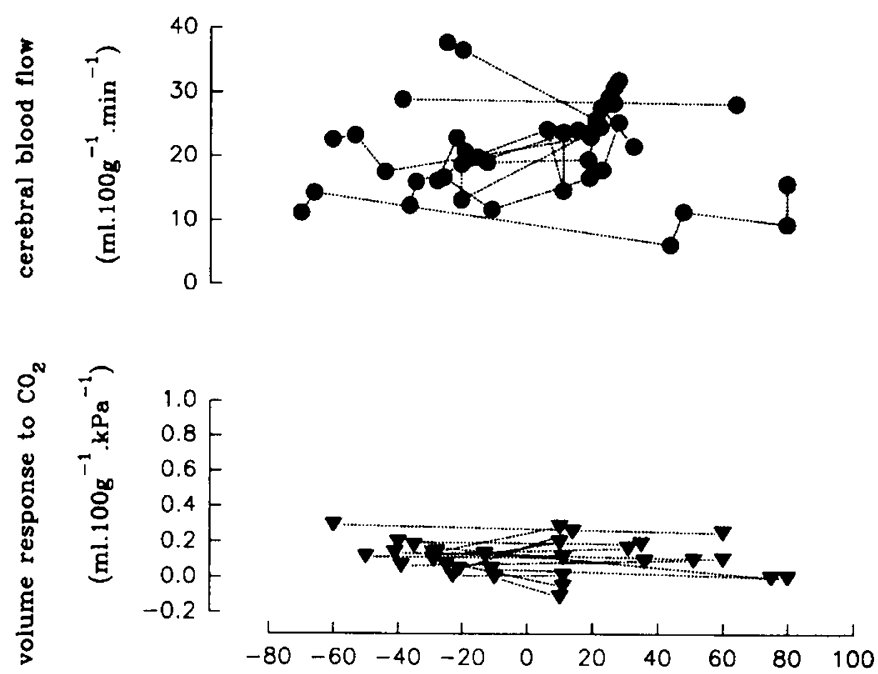

time (minutes)

Fig. 3. Values for $\operatorname{COD}(n=9), \operatorname{CBF}(n=9)$, and CBVR $(n=16)$ before and after surfactant administration. Surfactant was administered at $0 \mathrm{~min}$.

Table 2. Mean (SD) values for $C B F$ and $C O D$, and $C B V R$ during $90 \mathrm{~min}$ before and $90 \mathrm{~min}$ after surfactant

\begin{tabular}{lcc}
\hline & $\begin{array}{c}\text { Before } \\
\text { surfactant }\end{array}$ & $\begin{array}{c}\text { After } \\
\text { surfactant }\end{array}$ \\
\hline $\mathrm{CBF}\left(\mathrm{mL} \cdot 100 \mathrm{~g}^{-1} \cdot \mathrm{min}^{-1}\right)(n=9)$ & $20.5(7.5)$ & $23.1(5.2)$ \\
$\mathrm{COD}\left(\mathrm{mL} \cdot 100 \mathrm{~g}^{-1} \cdot \mathrm{min}^{-1}\right)(n=9)$ & $2.71(0.89)$ & $3.15(0.7)$ \\
$\mathrm{CBVR}\left(\mathrm{mL} \cdot 100 \mathrm{~g}^{-1} \cdot \mathrm{kPa}^{-1}\right)(n=16)$ & $0.14(0.09)$ & $0.11(0.11)$ \\
\hline
\end{tabular}

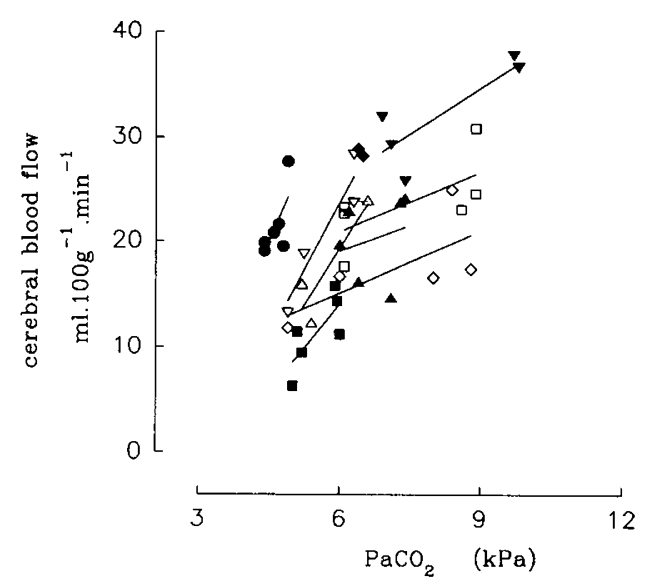

Fig. 4. The relation between $\mathrm{CBF}$ and $\mathrm{PaCO}_{2}$ in nine infants. Values from individual infants are denoted by different symbols, and the least squares regression line for each infant is indicated. 
before and after surfactant when the infants were in a stable condition showed no significant changes (Table 1). Values for $\mathrm{CBF}$ and COD were comparable to those previously obtained by NIRS and other techniques $(20,21)$. Because no effect of giving surfactant on these variables could be detected, these results do not suggest that this treatment causes persistent cerebral ischemia, although they do not exclude transient effects. The numbers of infants in this study limited its ability to detect small changes; however, the observation of a strong relation between $\mathrm{CBF}$ and $\mathrm{PaCO}_{2}$ (Fig. 4) shows that no effect greater than the effect of alterations in $\mathrm{PaCO}_{2}$ would have been missed. Because of this relation, $\mathrm{CBF}$ and $\mathrm{COD}$ are likely to have increased slightly rather than fallen during and after treatment due to the small associated rise in $\mathrm{PaCO}_{2}$ (Table 1).

Values for CBVR all fell within the $95 \%$ confidence limits for previously studied infants with normal brains (9). It has been suggested that a component of Curosurf might have an effect on the microvascular control of blood flow because flushing of the skin has been observed after treatment (4). We saw no such effect, and our finding that CBVR and the response of CBF to changes in $\mathrm{PaCO}_{2}$ (22) both appeared normal demonstrated that this aspect of microvascular control remained unimpaired. In addition, we found no relation between $\mathrm{CBV}$ or $\mathrm{CBF}$ and mean arterial blood pressure, which implies that cerebral perfusion remained independent of alterations in mean arterial blood pressure.

The present investigation was not designed to test the relation between cerebral hemodynamics and subsequent PVH. Nevertheless, perturbations associated with surfactant administration were no greater in the infants who developed PVH than in those who did not.

The results of this study of the effects of treatment with surfactant on cerebral oxygenation and hemodynamics do not provide evidence of persistent changes in $\mathrm{CBV}, \mathrm{CBF}, \mathrm{COD}$, or CBVR. The transient changes that were observed in CBV were relatively small and seem unlikely to be an independent factor provoking hemorrhage, although we cannot rule out the possibility. The incidence of PVH in the studies of Horbar et al. (2) therefore remains unexplained. It is possible that the details of the protocol for giving surfactant are important. For example, in our study we set out to minimize the effects of surfactant administration on chest movement, whereas the protocol of Horbar et al. (2) stated that immediately after the instillation of surfactant the $\mathrm{FiO}_{2}$ could be altered but not the airway pressure. Temporary obstruction of the airways might have caused an acute episode of impaired gas exchange. Alternatively, if the lung rapidly became more compliant as a result of treatment, it is possible that the intrathoracic circulation became obstructed, creating a situation analogous to the development of tension pneumothorax, which can be an important antecedent of PVH (23). Although these are many ways in which the cerebral circulation might be affected by the administration of surfactant, our results show that the procedure need not cause persistent major perturbations.

Acknowledgment. The authors thank the staff of the Neonatal Unit and the Department of Medical Physics and Bioengineering for their help.

\section{REFERENCES}

1. Tyson J, Silverman W, Reisch J 1989 Immediate care of the newborn infant. In: Chalmers I, Enkin M, Keirse MJNC (eds) Effective Care in Pregnancy and Childbirth. Oxford University Press, Oxford, UK, pp 1297-1301

2. Horbar JD, Soll RF, Schachinger H, Kewitz G, Versmold HT, Lindner W, Duc G, Mieth D, Linderkamp O, Zilow EP, Lemburg P, Von Loewenich V, Brand M, Minoli I, Moro G, Riegel KP, Roos R, Weiss L, Lucey JF 1990 A European multicentre randomised controlled trial of single dose surfactant therapy for idiopathic respiratory distress syndrome. Eur J Pediatr 149:416423

3. Svenningson NW, Hellstrom-Westas L, Rosen I 1990 Cerebral function and oxygenation before and after surfactant endotracheal instillation. Proceedings of the 5th International Workshop on Surfactant Replacement, Sestri Levante, Italy

4. Cowan F, Whitelaw A, Wertheim, D, Silverman M 1991 Cerebral blood flow velocity changes after rapid administration of surfactant. Arch Dis Child 66:1105-1109

5. Jobsis FF 1977 Noninvasive infrared monitoring of cerebral and myocardial sufficiency and circulatory parameters. Science 198:1264-1267

6. Cope M, Delpy DT 1988 A system for long term measurement of cerebral blood and tissue oxygenation in newborn infants by near-infrared transillumination. Med Biol End Comput 26:289-294

7. Wyatt JS, Cope M, Delpy DT, Wray S, Reynolds EOR 1986 Quantification of cerebral oxygenation and haemodynamics in sick newborn infants by near infrared spectroscopy. Lancet 2:1063-1066

8. Wyatt JS, Cope M, Delpy DT, Richardson CE, Edwards AD, Wray SC, Reynolds EOR 1990 Quantitation of cerebral blood volume in newborn human infants by near infrared spectroscopy. J Appl Physiol 68:1086-1091

9. Wyatt JS, Edwards AD, Cope M, Delpy DT, McCormick, DC, Potter A, Reynolds EOR 1991 Response of cerebral blood volume to changes in arterial carbon dioxide tension in preterm and term infants. Pediatr Res 29:553-557

10. Edwards AD, Wyatt JS, Richardson C, Delpy DT, Cope M, Reynolds EOR 1988 Cotside measurement of cerebral blood flow in ill newborn infants by near infrared spectroscopy. Lancet 2:770-771

11. Wray S, Cope M, Delpy DT, Wyatt JS, Reynolds EOR 1988 Characterisation of the near infrared absorption spectra of cytochrome $\mathrm{aa}_{3}$ and haemoglobin for the non-invasive monitoring of cerebral oxygenation. Biochim Biophys Acta 933:184-192

12. Wyatt JS, Cope M, Delpy DT, van der Zee P, Arridge S, Edwards AD, Reynolds EOR 1990 Measurement of optical pathlength for cerebral near-infrared spectroscopy in newborn infants. Dev Neurosci 12:140-144

13. Nelson SR, Mantz ML, Maxweil JA 1971 Use of specific gravity in the measurement of cerebral edema. J Appl Physiol 30:268-271

14. Lammertsma AA, Brooks DJ, Beaney RP, Turton DR, Kensett MJ, Heather JD, Marshall J, Jones T 1984 In vivo measurement of regional cerebral hematocrit using positron emission tomography. J Cereb Blood Flow Metab 4:317-322

15. Skov L, Pryds O, Greisen G 1991 Estimating cerebral blood flow in newborn infants: comparison of near infrared spectroscopy and ${ }^{133} \mathrm{Xe}$-clearance. Pediatr Res 30: 570-573

16. Bucher H-U, Lipp AE, Duc G, Edwards AD 1992 Comparison between ${ }^{133}$ Xenon clearance and near infrared spectroscopy for estimation of cerebral blood flow in sick preterm infants. Pediatr Res (in press)

17. Volpe JJ 1987 Neurology of the Newborn, 2nd Ed. Saunders, Philadelphia

18. Reynolds EOR, Wyatt JS 1992 Perinatal brain injury. In: Asbury A, McKhann GM, McDonald WI (eds) Diseases of the Nervous System, 2nd Ed. Saunders, Philadelphia, pp 584-597

19. Shah AR, Kurth CD Gwiazdowski SG, Chance B, Delivoria-Papadopoulos M 1992 Fluctuations in cerebral oxygenation and blood volume during endotracheal suctioning in premature infants, Pediatrics (in press)

20. Edwards AD, Wyatt JS, Richardson CE, Potter A, Cope M, Delpy DT, Reynolds EOR 1990 Effects of indomethacin on cerebral haemodynamics and oxygen delivery investigated by near infrared spectroscopy in very preterm infants. Lancet 335:1491-1495

21. Greisen G 1986 Cerebral blood flow in preterm infants during the first week of life. Acta Paediatr Scand 75:43-51

22. Pryds O, Greisen G, Lou H, Friis-Hansen B 1989 Heterogeneity of cerebral vasoreactivity in preterm infants supported by mechanical ventilation. J Pediatr 115:638-645

23. Thorburn RJ, Lipscomb AP, Stewart AL, Reynolds EOR, Hope PL 1982 Timing and antecedents of periventricular haemorrhage and of cerebral atrophy in very preterm infants. Early Hum Dev 7:221-238 